\title{
Synthesis and Characterization of Dual Properties Coagulant from Natural Precursors for Raw Water Treatment
}

\author{
Syazwani Mohd Asharuddin ${ }^{1}$, Norzila Othman ${ }^{*}$, Nur Shaylinda Mohd Zin ${ }^{1}$, \\ Mohd Fadhil Md. Din ${ }^{2}$, Vicky Kumar ${ }^{1}$
}

${ }^{1}$ Faculty of Civil Engineering and Built Environment,

Universiti Tun Hussein Onn Malaysia, 86400 Parit Raja, Johor, MALAYSIA

${ }^{2}$ Faculty of Civil Engineering,

Universiti Teknologi Malaysia, 81310 Skudai, Johor, MALAYSIA

*Corresponding Author

DOI: https://doi.org/10.30880/ijie.2020.12.08.025

Received 03 October 2019; Accepted 01 April 2020; Available online 15 September 2020

\begin{abstract}
A novel coagulant with dual properties was produced by manipulating the chemical characteristics of natural precursors. In the present study, cassava peel starch (CPS) was isolated from agriculture waste and lemongrass extract was procured using soxhlet extraction using ethanol. A preliminary study consisting of chemical analysis and antimicrobial test was done onto the lemongrass extract to ensure the presence of the active group responsible for antimicrobial effect. The modified cassava peel starch (MCPS) was synthesized using novel acidalkali grafting method to incorporate active compounds from lemongrass extract onto the starch backbone. The modified starch was subjected to Scanning Electron Microscopy coupled with Electron Dispersive X-Ray Spectrometry (SEM-EDX) for surface morphological and elementral distribution analysis. The molecular composition analysis was accomplished using Fourier Transform Infrared Spectrophotometry (FTIR) while the efficacy of the modification process was further analyze using proton Nuclear Magnetic Resonance Spectroscopy (1H NMR). The SEM-EDX and FTIR results revealed impressive changes in the physical surface morphology, elemental distribution and chemical structure of the starch post-modification. The results also indicated successful integration of lemongrass active groups onto the starch molecules which provides promising potential of the modified starch towards proposed application for water clarification and disinfection.
\end{abstract}

Keywords: Natural coagulants, flocculant, water disinfectant, water treatment, starch, modified starch

\section{Introduction}

Starch is one of the most abundant biological macromolecules on earth and can be find in numerous sources ranging from rice, wheat, tubers, fruits and vegetables. In the crude form, the skeletal framework of starch consists of a mixture of two polymers of anhydroglucose units, amylopectin and amylose. Amylopectin is a highly branched polymer of a-Dglucopyranosyl residues linked together by 1-4 linkages with 1-6 bonds at the branch points which these molecules compose the major component of most starches and plays an essential role in defining the characteristics of the starch. Whereby, amylose is a linear polymer of 1-4 linked a-D-glucopyranosyl units with low molecular weight, which makes up $25 \%$ of the starch [1].

In current years, starch-based flocculants have become more prominent in the field of water treatment due to their significant characteristics of widespread availability, low cost, environmental friendliness, and biodegradability. 
Moreover, owing to the attractive molecular composition of starch that contains large numbers of hydroxyl groups on its saccharide ring, starch can be easily modified chemically to satisfy various applications by the introduction of different functional groups onto its backbone [2,3]. A wide spectrum of modification techniques have been tested on starches from numerous sources and these starches were investigated for their flocculating abilities [1].

Dimethylamine-based, polyacrylamide-based and acrylamide-based graft copolymerisation is among the various modification techniques that most broadly studied in persistence to enhance the performance of starch to be potential coagulants. Unfortunately, along with the growing concern on human health effect, despite to their superior effect on water clarification, the technique has been blasted with critics due to the potential toxicity of the acrylamides. WHO [4] reported that following ingestion, acrylamide is readily absorb from the gastrointestinal tract and widely distributed in body fluids. It has the potential to cross the placenta, affect germ cells as well as impairs reproductive function. Additionally, human exposure via the consumption of drinking water treated with synthetic polyelectrolytes grafted with acrylamide revealed the development of widespread central and peripheral system dysfunction [5] The European standard only permits a maximal concentration of $0.1 \mathrm{mg} / \mathrm{L}$ for acrylamide and $0.5 \mathrm{mg} / \mathrm{L}$ for polyacrylamide with an acrylamide concentration of $0.02 \%$. Polymer restrictions have also been regulated because of their toxicity effects on the environment [6]. Several studies exposed the severe toxic effects of cationic polyacrylamide to aquatic life as the polymer tends to sorb on fish gills and causing gill lesions and increase frequency of necrotic cells [7]. Besides, polyacrylic acids, polystyrene sulfonic acids, and polyacrylamide are synthetized from nonrenewable oil-based materials and are considered hardly biodegradable [8].

Emerging concern associated with environmental drawbacks brought by the synthetic polyelectrolytes therefore have led to a significant research body aimed to replace the toxic monomers with natural and sustainable alternatives, which would eliminate the risks related to the presence of toxic monomers or impurities. There are possibilities of reducing exposure to the toxic chemical monomers carried by the treated water by using lower dosage of the chemical coagulants in combination with an alternative flocculant such as modified starch using natural monomers.

Hence, to the best of our knowledge, no studies have tested the modification process of starch incorporated with natural precursors such as lemongrass extract. Lemongrass extracts contains active ingredients like myrcene, citronellal, citronellol and geraniol [9]. In recent years, antibacterial property found in the extract of lemongrass has been elucidated from various researches with promising result. $\alpha$-citral (geranial) and $\beta$-citral (neral) are among the major bioactive compound that contributing to the antimicrobial activity of the extracts. These components possess the ability to inhibit the growth of both Gram positive and Gram negative bacteria [10].

Therefore, the present research discovers the potential usage of starch isolated from waste materials discarded from agricultural industries. New coagulant modification approach by avoiding toxic chemical monomers was proposed using the principle of acid-alkali crosslinking method by incorporating lemongrass extract intended to produce a flocculant with enhanced capability to aid flocculation and disinfection of Escherichia coli (E.coli) in the water.

\section{Materials and Method}

\subsection{Isolation of Starch}

Isolation of cassava peel starch (CPS) was performed according to the method described by Benesi [11] and Fakir et al. [12] with slight adjustment where the starch was isolated from cassava peels instead of cassava flesh. The cassava peels were procured from a local cassava chips factory. Good quality peels were selected and cleaned with tap water to remove any surface impurities. The outermost layers were scrapped off manually. $100 \mathrm{~g}$ peel then suspended in $200 \mathrm{ml}$ distilled water and pulverized using domestic blender for 5 minutes. Subsequently, $2000 \mathrm{~mL}$ of distilled water was added into the suspension and stirred for 2 minutes. Then the suspension was filtered using doubled fold muslin cloth and the filtrate was allowed to stand for 2 hours for sedimentation. Then the sediment was collected and sun dried for at least 24 hours to remove the moisture content. Dried CPS was kept in air tight glass container for further experimental use.

\subsection{Preparation of Lemongrass Extract}

Lemongrass stalks were purchased from local markets around Parit Raja, Johor, Malaysia. 500g of lemongrass stalks were fragmented into $10 \mathrm{~mm}$ long pieces and dried in oven at $60^{\circ} \mathrm{C}$ for 72 hours to remove the moisture content. The dried samples then were crushed using domestic blender to increase the surface area. The samples were stored in air-tight bottle for usage in subsequent extraction process [13,14].

$15 \mathrm{~g}$ of crushed lemongrass samples were added into extraction thimbles. $200 \mathrm{ml}$ of solvents $(95 \%$ ethanol and $95 \%$ methanol) were added into different round bottom flasks. Extraction using the soxhlet apparatus was done for 7 hours at $70^{\circ} \mathrm{C}$. After the extraction completed, the extracts were distilled off at $65^{\circ} \mathrm{C}$ using rotary evaporator. $10 \mathrm{~mL}$ of the final extracts were diluted into several concentrations $(20 \%-100 \%)$ using sterilized distilled water for antimicrobial test [15, 16]. Remaining extracts were stored in air-tight amber glass bottles at $4{ }^{\circ} \mathrm{C}$ for further analysis using FTIR and GC-MS. 


\subsection{Modification of Starch Using Lemongrass Extract}

Native CPS (25 g, dry basis) was suspended in $100 \mathrm{~mL}$ of $100 \% \mathrm{v} / \mathrm{v}$ ethanolic extract of lemongrass and stirred at $150 \mathrm{rpm}$ for 1 hour at $25^{\circ} \mathrm{C}$, then the reaction was started by adding $1 \mathrm{~mL}$ of concentrated ( $36 \%$ by weight) hydrochloric acid $(\mathrm{HCl})$ and allowed to proceed at $25^{\circ} \mathrm{C}$ for 24 hours with continuous stirring at $150 \mathrm{rpm}$. The reaction was stopped by adding $14 \mathrm{~mL}$ of $1 \mathrm{M}$ sodium bicarbonate (NaHCO3). The solution was cooled in ice-bath for $5 \mathrm{~min}$, and then centrifuged at $4000 \mathrm{rpm}$ for $5 \mathrm{~min}$. Subsequently, the precipitate was sun dried until it reached constant weight. Modified cassava peel starch (MCPS) were finally stored as solid powders to achieve long-term shelf stability.

\subsection{Physico-Chemical Study of CPS and MCPS}

The surface morphology and chemical composition were observed through SEM-EDX (JEOL JSM-6380LA) spectroscopy. The surface chemical functional groups of both CPS and MCPS were characterized by Fourier transform infrared (FTIR, Perkin Elmer Spectrum 100) spectroscopy with the measured wavenumber from 400 to $4000 \mathrm{~cm}-1$ and $1 \mathrm{H}$ nuclear magnetic resonance $\left(1 \mathrm{H}\right.$ NMR, Bruker AVANCE Model DRX-500) spectroscopy using $\mathrm{D}_{2} \mathrm{O}$ as solvent. The X-ray patterns of the starches were obtained using an XRD-6100 diffractometer (Shimazu Co., Kyoto, Japan) within scanning region of the two-theta angle being from $4^{\circ}$ to $37^{\circ}$.

\section{Results and Discussion}

\subsection{Characterization of Lemongrass Extract}

Characterization study was carried out by FTIR analysis to know about the complex formation and interaction of major functional groups involved in the modification of the CPS. These results helped in confirming the presence of important active functional groups that make up the antimicrobial compound in lemongrass extract.

As presented in Fig. 1, the adsorption band structures observed between 3150 and $3000 \mathrm{~cm}^{-1}$ are almost exclusively indicative of unsaturation $(\mathrm{C}=\mathrm{C}-\mathrm{H})$ and/or aromatic rings and their presence in the IR spectrograph obtained is thus indicative of the presence of aromatic compounds [17]. The strong methylene/methyl band $\left(1446.5 \mathrm{~cm}^{-1}\right)$ and a weak methyl band $\left(1384.8 \mathrm{~cm}^{-1}\right)$, plus a band at $740 \mathrm{~cm}^{-1}$ (methylene rocking vibration) is indicative of a long-chain linear aliphatic structure. The saturated hydrocarbon C- H stretching absorptions all occur below $3000 \mathrm{~cm}^{-1}$. Carbonyl compounds are often the strongest band in the spectrum and lie between $1700-1500 \mathrm{~cm}^{-1}$ its exact position being dependent upon its immediate substituent. For a double-bonded functionality, conjugation plays an important role in the observed carbonyl frequency. This includes connection to an aromatic ring or conjugation to a $\mathrm{C}=\mathrm{C}$ or another $\mathrm{C}=\mathrm{O}$ [17]. According to Natrajan et al. [18], the peak in the range of $1700-1500 \mathrm{~cm}-1$ indicating the presence of citral, an antimicrobial compound in lemongrass oil. The FTIR result obtained in the present study is also comparable to pure geraniol compound which showed similar presence of functional groups including $\mathrm{OH}-\mathrm{CH}_{3-}, \mathrm{C}=\mathrm{C},-\mathrm{C}=\mathrm{CH}-$ and $\mathrm{C}-\mathrm{O}-$ $\mathrm{H}$ [19]. Geraniol is a form of citral, a constituent of lemon grass and lemongrass essential oil (up to $85 \%$ of volatile oil content) have been found to exhibit a potent antibacterial action against various pathogens including Escherichia coli and Salmonella enterica [9].

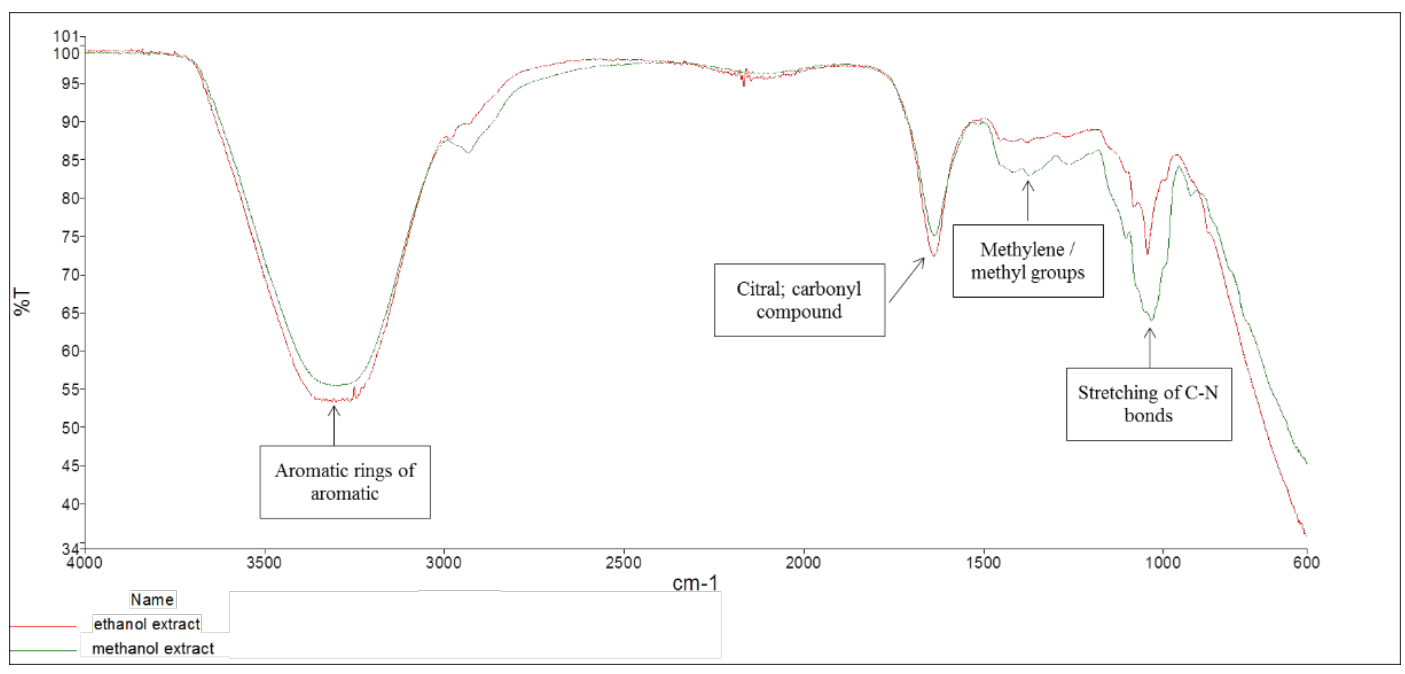

Fig. 1 - FTIR spectrum of ethanolic and methanolic extract of lemongrass

GC-MS analyses were performed with the aim to compare the compositions of the ethanolic and methanolic extract of lemongrass. It was observed that citral is the major compound found in both lemongrass extracts of ethanol and methanol as the solvents (Fig. 2 and Fig. 3). However, the intensity is significantly higher for ethanolic extract. 
Citral, an acyclic monoterpene aldehyde is the key constituent to evaluate the quality of lemongrass extracts [20, $21]$. Citral is a racemic mixture of two isomers, geranial ( $\alpha$-citral) and neral ( $\beta$-citral) and commonly used as a raw material for the perfumery, cosmetics and pharmaceutical industries including the synthesis of vitamin A [9].

According to a review on antibacterial activity of lemongrass extracts written by Mosquera et al. [22], a number of components have been identified in the essential oil extract of the plant. Although there is variability in the percentages found, there is consistency in its major components, including citral. Additionally, Negrelle \& Gomes [23] have pointed out that irrespective of the lemongrass origin, the essential oils of Cymbopogon citratus are mainly composed of citral (30 to 93.74\%).10 Tests have been carried out to identify the metabolites responsible for the antibacterial activity. These activities are shown in two of the three main components of oil, identified through chromatography and mass spectrometry methods. While the components (neral) $\alpha$-citral and (geranial) $\beta$-citral cause individually antibacterial action on gram-negative and gram-positive strains, while the third component, myrcene on its own shows no antibacterial activity.

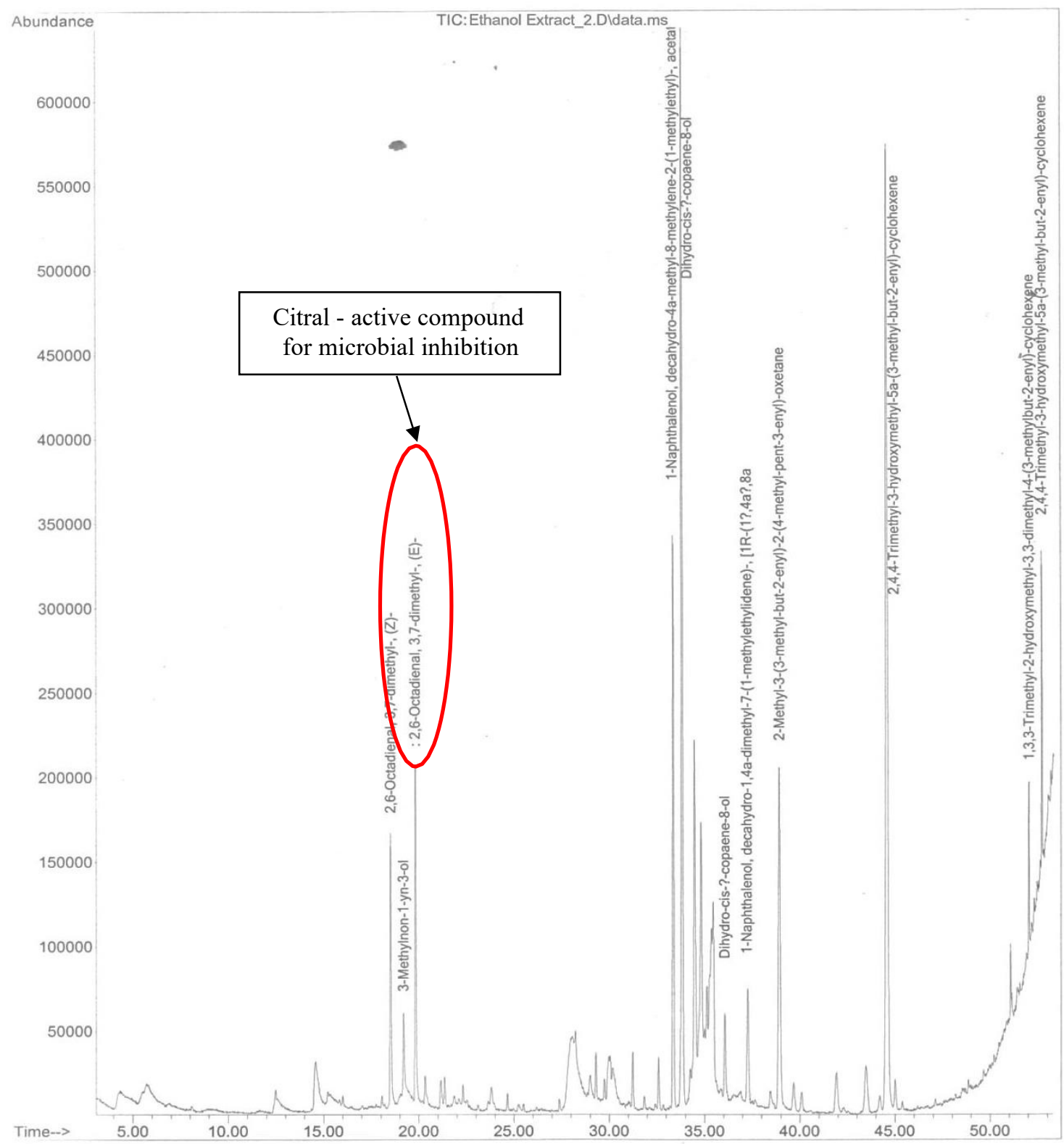

Fig. 2 - GC-MS spectrum of ethanolic extract of lemongrass 


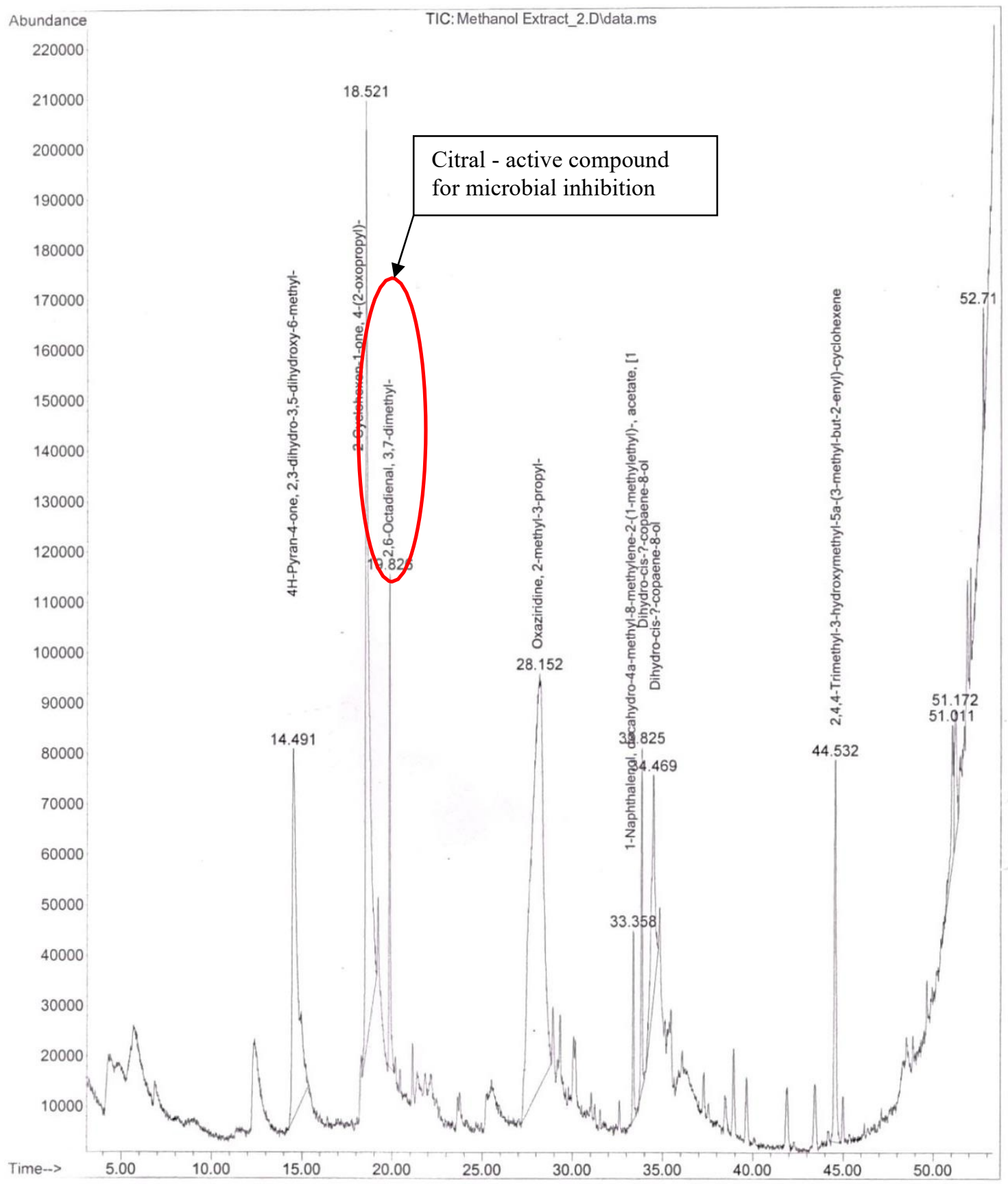

Fig. 3 - GC-MS spectrum of methanolic extract of lemongrass

\subsection{Antimicrobial test of lemongrass extract against $\boldsymbol{E}$.coli}

Results of the antimicrobial activity of lemongrass extracts portrayed the growth inhibition effects were detected using Kirby-Bauer method as presented in Fig. 4. The extracts were tested on gram negative bacteria - E.coli. Based on the zone of inhibition as tabulated in Table 1, the ethanol extract indicates better antimicrobial activity compared to methanol extract with highest diameter of inhibition zone recorded at $27 \mathrm{~mm}$ for $100 \%$ extract concentration which is comparable to the diameter of inhibition zone recorded for ampicillin antibiotic $(28 \mathrm{~mm})$.

The comparative effects of different concentration of lemongrass extracts and the standard antibiotic disc on the target organism are demonstrable indications of the extract as an antibacterial agent. The results obtained were comparable to other antimicrobial studies described by several literatures [24]-[26]. Similar antibiotic susceptibility pattern also had been reported by Onawunmi \& Ongulana [27] and the authors suggested that the test organisms particularly gram negative were found to be more susceptible to lemongrass extracts than standard antibiotic. 


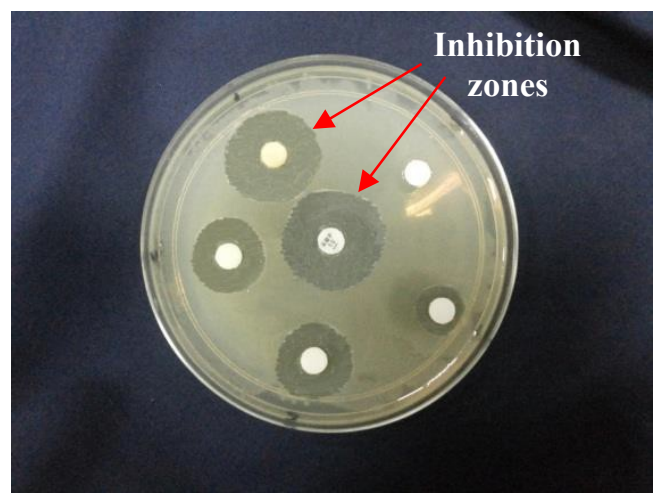

Fig. 4 - Antimicrobial test using Kirby-Bauer method

Table 1 - Inhibition zone diameter of lemongrass extracts against E.coli

\begin{tabular}{cccccc}
\hline \multirow{2}{*}{$\begin{array}{c}\text { Test } \\
\text { organism }\end{array}$} & $\begin{array}{c}\text { Extract } \\
\text { concentration } \\
(\%)\end{array}$ & $\begin{array}{c}\text { Ethanol } \\
\text { extract }\end{array}$ & $\begin{array}{c}\text { Methanol } \\
\text { extract }\end{array}$ & $\begin{array}{c}\text { Ampicilin } \\
\text { antibiotic } \\
\text { (positive control) }\end{array}$ & $\begin{array}{c}\text { Blank disk } \\
\text { (negative control) }\end{array}$ \\
\hline \multirow{5}{*}{ E.coli } & $20 \%$ & 11 & 7 & & \\
& $40 \%$ & 15 & 13 & 28 & - \\
& $60 \%$ & 20 & 15 & & \\
\hline
\end{tabular}

\subsection{Characterization of Native and Modified Starch}

As presented in Fig. 5, CPS presented smooth and non-porous surface with starch granules were appeared in irregular spherical in shape, truncated and bowl-shaped topography structure. Some ridges were also identified that appear to mark sites where granules were in close contact with one another. These observations were in parallel with morphological studies of native cassava starch conducted by Charoenkul et al. [28] and Xia et al. [29]. The microscopic analysis of MCPS showed small pores were detected in minimal amount and the starch granule surface appeared to be rough and wave-like creases were spotted as reported by Palacios-Fonseca et al. [30].

Generally, the starch granules sizes of the CPS and MCPS were observed in the range of $6-13 \mu \mathrm{m}$. These sizes were comparable to those reported by Charoenkul et al. [28] (4-20 $\mu \mathrm{m})$, Niba et al. [31] (9-20 $\mu \mathrm{m})$, Sriroth et al. [32] (8 - $22 \mu \mathrm{m})$,), Ji et al. [33] $(10-20 \mu \mathrm{m})$ and Monroy et al. [34] (6-12 $\mu \mathrm{m})$. According to Lindeboom et al. [35], starch granules can be into four size classes: large (greater than $25 \mu \mathrm{m})$, average (10 to $25 \mu \mathrm{m})$, small $(5$ to $10 \mu \mathrm{m})$, and very small (less than $5 \mu \mathrm{m}$ ). The granules in the storage roots were observed to be larger in diameter than in the fibrous root. The granule size increased from the outermost layer towards the innermost layer of the storage roots. The size of starch granules plays an important role in the modification of the microstructure due to a capacity for trapping kinetic energy [36].

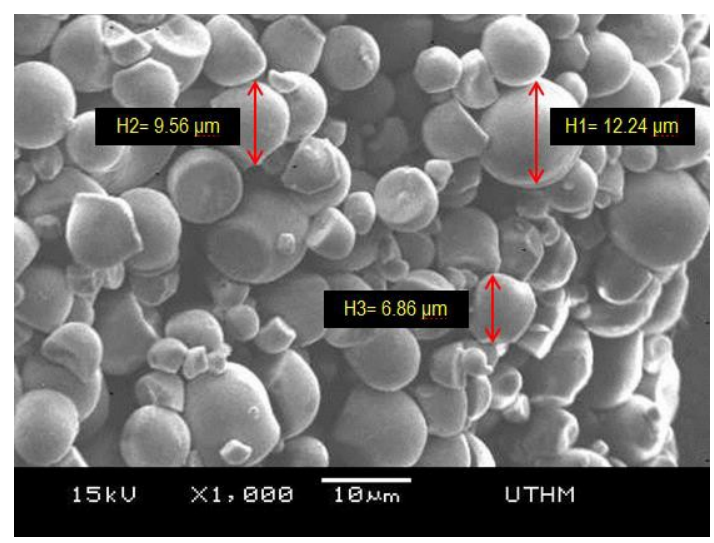

a)

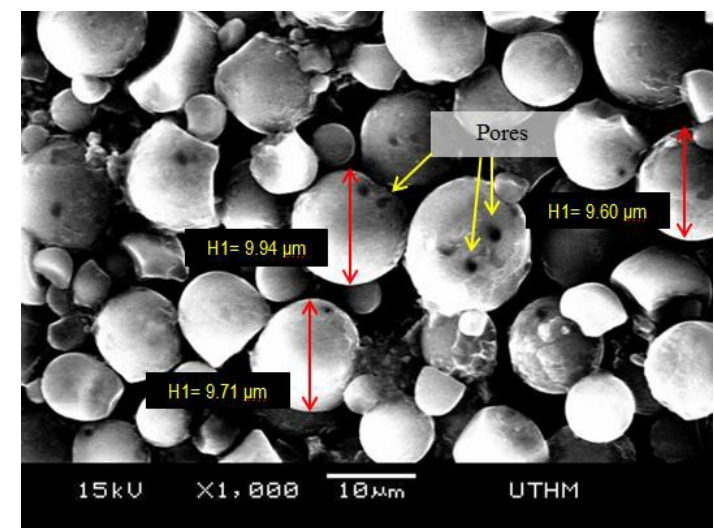

b)

Fig. 5 - SEM micrograph of (a) native CPS at X1000 (b) MCPS at X1000 
The differences in the elemental contents between native CPS and MCPS samples were observed. The EDX analysis done on the native CPS only identifies the presence of prominent $\mathrm{C}$ and $\mathrm{O}$ peaks which confirm the supposition that the starch granules were purely made up from carbohydrate monomers (Fig. 6). However, apparently, the modification of CPS using lemongrass extract and hydrochloric acid had imposed the surface elemental characteristic of the MCPS that increasing the possibility of antimicrobial ability and retaining metallic ions in different parts of the coagulant which is supported by the findings obtained from EDX analysis as presented in Fig. 7. Elements of $\mathrm{Na}, \mathrm{K}$ and $\mathrm{Ca}$ were found in very minimal percentage in the native CPS, whereas a significant percentage of these elements were detected in the modified samples with significant addition of $\mathrm{Cl}$ element. The appearance on those elements in the MCPS indicates the occurrence of modification and proved that the modifying agents, lemongrass extract and $\mathrm{HCl}$ were grafted onto the cassava peel starch.

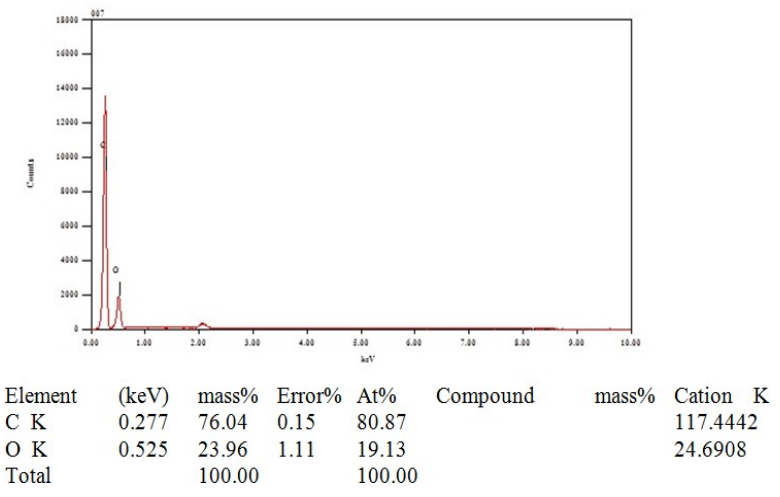

Fig. 6 - EDX spectrum of CPS

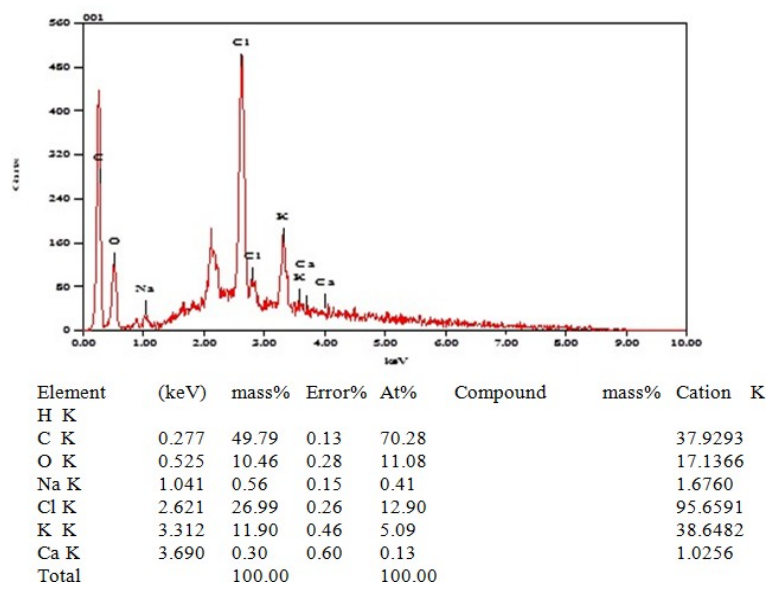

Fig. 7 - EDX spectrum of MCPS

The molecular level changes of the starch resulted from the modification process were evaluated using FTIR and the spectra are showed in Fig. 8. According to Kacurakova et al. [37], FT-IR spectra within the range of $1200 \pm 800 \mathrm{~cm}^{-1}$ region indicating the main polysaccharides present in the complicated systems of polysaccharide mixtures. The overall shape of a polysaccharide spectrum is determined by the backbone polysaccharide composition but can also be strongly influenced by the side chain constituents. The broad band observed between $3500-3200 \mathrm{~cm}^{-1}$ may be assigned to O-H groups of free hydroxyl groups and bonded O-H group in polymeric compounds such as alcohols, phenols and carboxylic acids presented in pectin, cellulose and lignin on the CPS. The peak at wavenumber between $3000-2850 \mathrm{~cm}^{-1}$ may indicate the stretch of symmetric or asymmetric $\mathrm{CH}, \mathrm{CH}_{2}$, of aliphatic acids. Furthermore, the characteristic peak appeared between $1750-1680 \mathrm{~cm}^{-1}$ are demonstrating the stretching vibration of $\mathrm{C}=\mathrm{O}$ bond of carboxyl groups. Whereas the peaks observed between $1375-1300 \mathrm{~cm}^{-1}$ may reflect the stretching vibration of ionic carboxylic groups of pectin. While the deep peaks between $1300-1000 \mathrm{~cm}^{-1}$ indicate the $\mathrm{C}-\mathrm{O}$ stretching of $-\mathrm{C}-\mathrm{O}-\mathrm{OH}$ side group and C-O-C gycosidic bond vibration. The results were in agreement with FTIR analysis done onto native starch by other studies as summarized in Table 2.

Distinctive changes were found where the peak intensity for MCPS at $1016 \mathrm{~cm}^{-1}$ was increased significantly. Compared to the peaks for native CPS within the wavenumber of $1400-1200 \mathrm{~cm}^{-1}$, the peaks for MCPS were observed to be reduced and shifted towards $1500 \mathrm{~cm}^{-1}$. This region was characteristic of aliphatic amines. Similarly, prominent broad peak between $3750-3200 \mathrm{~cm}^{-1}$ which assigned to $\mathrm{O}-\mathrm{H}$ group of free hydroxyl groups and bonded O-H group in polymeric compound was also observed to be shifted after modification process took place from $3263 \mathrm{~cm}^{-1}$ to $3436 \mathrm{~cm}^{-1}$ [37].

Furthermore, the characteristic peak appeared between $1750-1680 \mathrm{~cm}^{-1}$ are demonstrating the stretching vibration of $\mathrm{C}=\mathrm{O}$ bond of carboxyl groups. Whereas the peaks observed between $1375-1300 \mathrm{~cm}^{-1}$ may reflect the stretching vibration of ionic carboxylic groups of pectin. While the deep peaks between $1300-1000 \mathrm{~cm}^{-1}$ indicate the C-O stretching of -C-O-OH side group and C-O-C gycosidic bond vibration [38].

It was clearly observed from the FTIR spectrum that carboxyl and hydroxyl groups were present in abundant since cassava peel starch is principally composed of glucose monomers. These groups that constituted in biopolymers may function as proton donors; hence deprononated hydroxyl and carboxyl groups may be involved in the formation of floc complex when the starch is applied together with primary coagulant. The primary coagulant may initially forms micro flocs which gradually grow to become macro flocs when the MCPS is added. Moreover, many observations made on bioflocculants suggest that carboxyl, hydroxyl, carbonyl as well as amino (amine and amide) groups were the preferred groups contributing towards the flocculating ability of the biomaterial [39]. The functional groups plays the key role for the flocculation process via two methods that are hydrophilicity characteristics which are utilized to extend the polymer chain; and the functional groups extent the gap between particles to effectively adsorbs the particles [40]. 


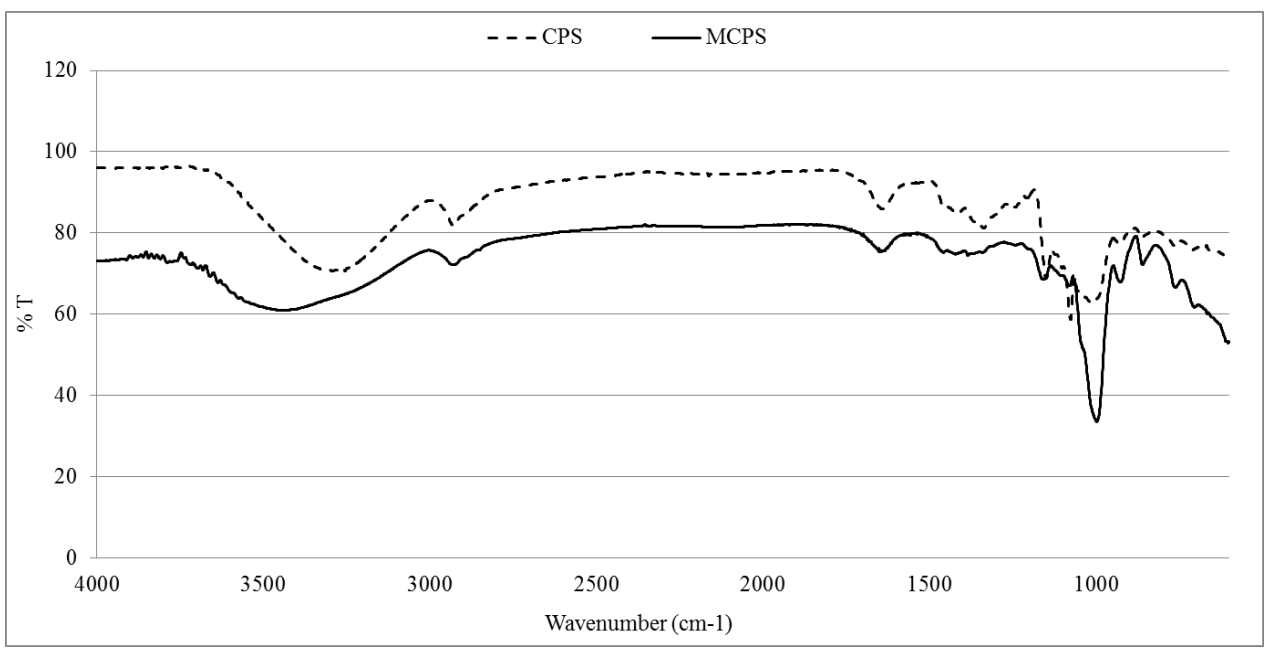

Fig. 8 - FTIR spectrum of CPS and MCPS

Table 2 - Summary of functional groups identified in native starches

\begin{tabular}{cccc}
\hline & \multicolumn{3}{c}{ Wavelength range $\left(\mathrm{cm}^{-1}\right)$} \\
\cline { 2 - 4 } Identified groups & $\begin{array}{c}\text { CPS } \\
\text { (present study) }\end{array}$ & $\begin{array}{c}\text { Cassava starch } \\
\text { (Lomelí-Ramírez et al. } \\
\text { [41]). }\end{array}$ & $\begin{array}{c}\text { Tapioca starch } \\
\text { (Sacithraa et. al. [42]) }\end{array}$ \\
\hline $\begin{array}{c}\text { O-H groups of free } \\
\text { hydroxyl groups and } \\
\text { bonded O-H }\end{array}$ & $3500-3200$ & 3300 & $4000-2500$ \\
$\begin{array}{c}\text { Symmetric or assymetric } \\
\text { stretching of CH, CH } \text { Cf }_{2} \text { of } \\
\text { aliphatic acids }\end{array}$ & $3000-2850$ & 2926 & $3000-2850$ \\
$\begin{array}{c}\text { Stretching vibration of } \\
\mathrm{C}=\mathrm{O} \text { bond of carboxyl } \\
\text { groups }\end{array}$ & $1750-1680$ & 1715 & $2000-1500$ \\
$\mathrm{C}-\mathrm{O}$ stretching of COOH & $1300-1000$ & 1160 & $1242-1016$ \\
\hline
\end{tabular}

The crystallinity of starch is related to amylopectin linear chains which may give different $X$-ray diffraction patterns depending on starch source [43]. As can be seen in Fig. 9, both CPS and MCPS exhibited same typical A-type crystalline pattern with strong reflections at about $2 \theta 16^{\circ}$ and $24^{\circ}$ and unresolved doublet at $2 \theta 18^{\circ}$ and $19^{\circ}$. Similar crystalline pattern of starch were also reported by Shariffa et al. [44]; Mohd et al. [45]; Gao et al. [46]. This result supported the hypothesis chemical modifications had little effects on the crystalline structure, but rather concentrated primarily in the amorphous lamellae of starch granules [47].

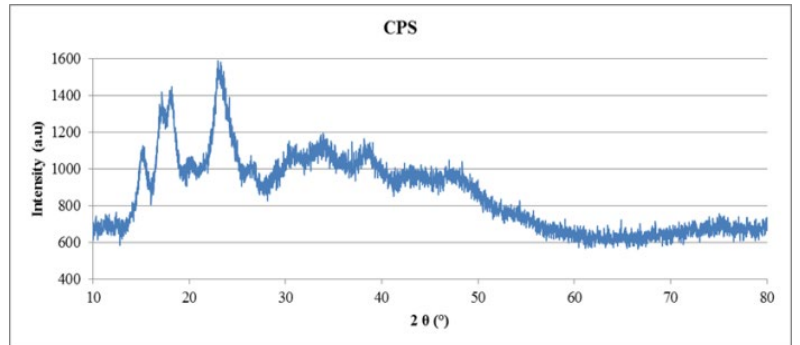

(a)

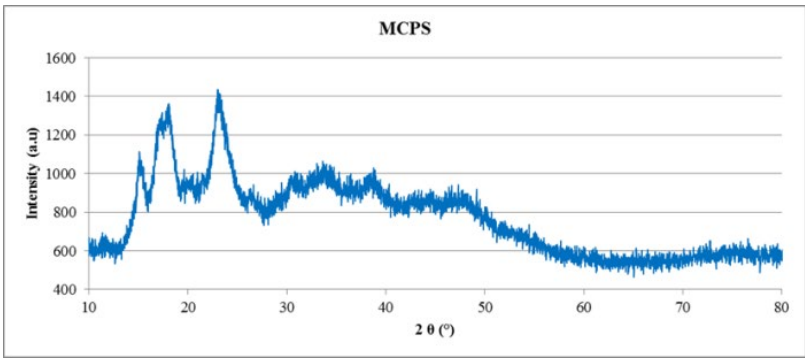

(b)

Fig. 9 - XRD spectra of (a) native CPS and (b) MCPS

According to Harry et al. [48], the crystalline pattern of starch can be classified into four types, A, B, C and V type. Type $\mathrm{A}, \mathrm{B}$ and $\mathrm{C}$ are the crystal structures of natural starches whereas the $\mathrm{V}$ type are complexes formed by amylose and lipids. A-form starch gives stronger diffraction around $2 \theta 15^{\circ}, 17^{\circ}, 18^{\circ}$ and $23^{\circ}$ with absence of peak in the range, $5^{\circ}$ to $6^{\circ}$. B-form possesses strongest diffraction at $17^{\circ}$ and other smaller peaks at $20^{\circ}, 22^{\circ}$ and $24^{\circ}$. C pattern is a mixture of A and $\mathrm{B}$. The present X-Ray diffraction studies also proved that modified CPS suffered change in crystallinity. Reduction 
of intensities was observed after the modification process which suggesting change in crystallinity of the starch after the treatment. Such lowered reflection of intensities could most likely be attributed to the weakened or partial destruction of inter and intra molecular hydrogen bonds in amylopectin [46]. Gao et al. [46] also suggested that partial destruction of crystal structure of starch could allow more hydroxyl groups to react with other species in aqueous solution. The starch crystallinity can be affected by by four factors including crystal size, the number of crystalline region affected by crystalline content and length of chain, the orientation of double helices within the crystalline area and the extent of interaction between the double helices [45, 46]. Tukomane et al. [46] also reported that crystalline region is an ordered arrangement of double helical amylopectin structures which reduces with increase in the amylose and is increased by hydrolysis of starch.

\section{Summary}

The integration of active groups from lemongrass extract onto cassava peel starch was successfully accomplished. The observation showed the modified starch undergone minor changes in the physical characteristics by the signs of wave-like creases on the surface and slightly shifted crystalline structure. Moreover, the chemical characteristics of the modified starch were observed to be significantly altered following the modification treatment. Therefore, the results from the present study provide promising potential of manipulating natural precursors as alternative for starch modification in order to enhance the starch properties as flocculant and disinfectant for water treatment.

\section{Acknowledgement}

This work was funded through Fundamental Research Grant Scheme (FRGS Vot. 1575) supported by Ministry of Higher Education of Malaysia (MOHE).

\section{References}

[1] Oladoja, N. A., Unuabonah, E. I., Amuda, O. S. \& Kolawole, O. M. (2017). Polysaccharides as a green and sustainable resource for water and wastewater treatment. Biobased Polymers, 10, 13-35.

[2] Huang, M., Liu, Z., Li, A. \& Yang, H. (2017). Dual functionality of a graft starch flocculant: Flocculation and antibacterial performance. Journal of Environmental Management, 196, 63-71.

[3] Mohd Asharuddin, S., Othman, N., Mohd Zin, N. S., Tajarudin, H. A. \& Md Din, M. F. (2018). Performance assessment of cassava peel starch and alum as dual coagulant for turbidity removal in dam water. International Journal of Integrated Engineering, 10, 185-192.

[4] WHO Seminar Pack for Drinking-Water-Quality, Water Treatment Chemicals and Construction Materials, 2000.

[5] Besaratinia, A. \& Pfeifer, G. P. (2007). A review of mechanisms of acrylamide carcinogenicity. Carcinogenesis, 28, 519-528.

[6] Lapointe, M. \& Barbeau, B. (2015). Evaluation of activated starch as an alternative to polyacrylamide polymers for drinking water flocculation. Journal of Water Supply and Resource Technology, 64, 333-343.

[7] Kerr, J. L., Lumsden, J. S., Russell, S. K., Jasinska, E. J. \& Goss, G.G. (2014). Effects of anionic polyacrylamide products on gill histopathology in juvenile rainbow trout (Oncorhynchus mykiss). Environmental Toxicology Chemistry, 33, 1552-1662.

[8] Xing, W., Guo, W., Ngo, H. H., Cullum, P. \& Listowski, A. (2010). Integration of inorganic micronutrients and natural starch based cationic flocculant in primary treated sewage effluent (PTSE) treatment. Separation Science and Technology, 45, 619-625.

[9] Manvitha, K. \& Bidya, B. (2014), Review on pharmacological activity of Cymbopogon citratus. International Journal of Herbal Medicine, 1, 5-7.

[10] Olorunnisola, S. K., Asiyanbi, H. T., Hammed, A. M. \& Simsek, S. (2014). Biological properties of lemongrass: An overview. International Food Research Journal, 21, 455-462.

[11] Benesi, I. R. M. (2005). Characterisation of Malawian cassava germplasm for diversity, starch extraction and its native and modified properties. PhD Thesis, University of The Free State, Bloemfontein, South Africa.

[12] Fakir, M. S. A., Jannat, M. Mostafa M. G. \& Seal H. (2012), Starch and flour extraction and nutrient composition of tuber in seven cassava accessions. Journal of Bangladesh Agriculture University, 10, 217-222.

[13] Tajidin, N. E., Ahmad, S. H., Rosenani, A. B., Azimah, H. \& Munirah, M. (2012). Chemical composition and citral content in lemongrass (Cymbopogon citratus) essential oil at three maturity stages. African Journal of Biotechnology, 11, 2685-2693.

[14] Lee, L. Y., Lee, X. J., Chia, P. C., Tan, K. W. \& Gan, S. (2014). Utilisation of Cymbopogon citratus (lemon grass) as biosorbent for the sequestration of nickel ions from aqueous solution: Equilibrium, kinetic, thermodynamics and mechanism studies. Journal of the Taiwan Institute of Chemical Engineers, 45, 1764-1772.

[15] Jafari, B., Ebadi, A., Aghdam, B. M., \& Zarifeh Hassanzade, Z. (2012). Antibacterial activities of lemon grass methanol extract and essence on pathogenic bacteria. American-Eurasian Journal of Agricultural and Environmental Sciences., 12, 1042-1046. 
[16] Nur Ain. A. H., Zaibunnisa, A. H., Halimahton Zahrah, M. S. \& Norashikin, S. (2013). An experimental design approach for the extraction of lemongrass (Cymbopogon citratus) oleoresin using pressurised liquid extraction (PLE). International Food Research Journal, 20, 451-455.

[17] Madivoli, E. S., Gitu, L. \& Elijah, G. (2012). Isolation and identification of essential oils from Cymbopogan citratus (stapf) dc using GC-MS and FTIR. Materials Research, 2, 13-23.

[18] Natrajan, D., Sharmila Srinivasan, K. \& Sundar, A. R. (2015). Formulation of essential oil-loaded chitosanealginate nanocapsules. Journal of Food and Drug Analysis, 23, 1-9.

[19] Arputha, B. M., Selvamani, P. \& Latha, S. (2012). In-vitro antimicrobial evaluation of extracts, oil and fractionated geraniol of Cymbopogan citratus-an aromatic grass. International Journal of Environmental Sciences, 3, 584-590.

[20] Mirghani, M. E. S., Liyana, Y. \& Parveen, J. (2012). Bioactivity analysis of lemongrass (Cymbopogan citratus) essential oil. International Food Research Journal, 19, 569-575

[21] Ranitha, M., Abdurahman, H. N., Sulaiman, Z. A., Nour, A. H. \& Thana Raj, S. (2014). A comparative study of lemongrass (Cymbopogon Citratus) essential oil extracted by microwave-assisted hydrodistillation (MAHD) and conventional hydrodistillation (HD) method. International Journal of Chemical Engineering and Applications, 5, 104-108.

[22] Mosquera, T. T., Noriega, P. R., Juan, C. C. \& de Lourdes Pardo, M. (2016). Biological Activity of Cymbopogon citratus (DC) Stapf and Its Potential Cosmetic Activities. International Journal of Phytocosmetics and Natural Ingredients, 3, 1-7.

[23] Negrelle, R. R. B. \& Gomes, E. C. (2007). Cymbopogon citratus (Dc) stapf: Chemical composition and biological activities. Revolution of Brasilian Plant Medical Botucatu, 9, 80-92.

[24] Naik, M. I., Fomda, B. A., Jaykumar, E. \& Bhat, J. A. (2010). Antibacterial activity of lemongrass (Cymbopogon citratus) oil against some selected pathogenic bacterias. Asian Pacific Journal of Tropical Medicine, 33, 535-538.

[25] Ewansiha J. U., Garba S. A., Mawak J. D. \& Oyewole O. A. (2012). Antimicrobial activity of Cymbopogon citratus (Lemongrass) and it's phytochemical properties. Frontiers in Science, 2(6), 214-220.

[26] Maheswari, R. U. \& Eugin Amala, V. (2015). Analyzing and determining the activity of antimicrobial, functional group and phytochemicals of Cymbopogon citratus using Well, FT-IR and HPLC. International Journal of Science and Research, 4, 138-141.

[27] Onawunmi, G. O., Yisak, W. A. \& Ogunlana, E. O. (1984). Antibacterial constituents in the essential oil of Cymbopogon citratus (DC.) stapf. Journal of Ethnopharmacolog, 12, 279-86.

[28] Charoenkul, N., Uttapap, D., Pathipanawat, W. \& Takeda, Y. (2011). Physicochemical characteristics of starches and flours from cassava varieties having different cooked root textures. Food Science and Technology, 44, 17741781.

[29] Xia, H., Li, B. Z. \& Gao, Q. (2017). Effect of molecular weight of starch on the properties of cassava starch microspheres prepared in aqueous two-phase system. Carbohydr Polymer, 1, 334-340.

[30] Palacios-Fonseca, A. J., Castro-Rosas, J., Gómez-Aldapa, C. A., Tovar-Benítez, T., Millán-Malo, B. M., del Real, A. \& Rodríguez-García, M. E. (2013), Effect of the alkaline and acid treatments on the physicochemical properties of corn starch, CyTA. Journal of Food, 11, 67-74.

[31] Niba, L., Bokanga, M., Jackson, F., Schlimme, D. \& Li, B. (2002). Physicochemical properties and starch granular characteristics of flour from various Manihot esculenta (cassava) genotypes. Journal of Food Science, 67, 17011705.

[32] Sriroth, K., Santisopasri, V., Petchalanuwat, C., Kurotjanawong, K., Piyachomkwand, K. \& Oates, C. G. (1999). Cassava starch granule structure-function properties: infuence of time and conditions at harvest on four cultivars of cassava starch. Carbohydrate Polymers, 38, 161-170.

[33] Ji, Y., Seetharaman, K. \& White, P. J. (2004). Optimizing a smallscale corn-starch extraction method for use in the laboratory. Cereal Chemistry, 81, 55-58.

[34] Monroy, Y., Rivero, S. \& García, M. (2018). Microstructural and techno-functional properties of cassava starch modified by ultrasound. Ultrasonics-Sonochemistry, 42, 795-804.

[35] Lindeboom, N., Chang, P. R. \& Tyler, R. T. (2004). Analytical, biochemical and physicochemical aspects of starch granule size, with emphasis on small granule starches: A review. Starch, 56, 89-99.

[36] Carmona-García, R. L., Bello-Pérez, A. A., Aguirre-Cruz, A., Aparicio-Saguilán, J., Hernández-Torres, J. \& Alvarez-Ramirez, J. (2016). Effect of ultrasonic treatment on the morphological, physicochemical, functional, and rheological properties of starches with different granule size. Starch, 68, 972-979.

[37] Kacurakova, M., Capeka, P., Sasinkova, V., Wellner, N. \& Ebringerova, A. (2000). FT-IR study of plant cell wall model compounds: pectic polysaccharides and hemicelluloses. Carbohydrate Polymers, 43, 195-203.

[38] Othman, N. \& Mohd Asharuddin, S. (2013). Cucumis melo rind as biosorbent to remove Fe(II) and Mn(II) from synthetic groundwater solution. Advanced Materials Research, 795, 266-271.

[39] Khamidun, N. H., Fulazzaky, M. A., Din, M. F. M. \& Yusoff, A. R. M. (2014). Resistance of mass transfer, kinetic and isotherm study of ammonium removal by using a hybrid plug-flow column reactor (HPFCR). Environment, Energy and Sustainable Development, 555-559. 
[40] Yuan, S. J., Minsun., Pingsheng, G., Li, Y., Li, W. W., Yao, R. S. \& Yu, H. Q. (2011). Identification of key constituentsand structure of the extracellular polymeric substances excreted by Bacillus megaterium TF10 for their flocculation capacity. Environmental Science and Technology, 45, 1152-1157.

[41] Lomelí Ramírez, M. G., Satyanarayana, K. G., Iwakiri, S., Bolzon de Muniz, G., Tanobe, V. \& Flores-Sahagun, T. S. (2011). Study of the properties of biocomposites. Part I. Cassava starch-green coir fibers from Brazil. Carbohydrate Polymers, 86, 1712-1722.

[42] Sacithraa, R., Madhan-Mohan, M. \& Vijayachitra, S. (2013). Quantitative analysis of tapioca starch using FT-IR spectroscopy and partial least squares. International Journal of Computer Applications, 1, 29-33.

[43] Buléon, A., Gallant, D. J., Bouchet, B., Mouille, C., D'Hulst, Kossmann, C. J. \& Ball, S. (1997). Chlamydomonas veinhardtii as a model microbial system to investigate the biosynthesis of the plant amylopectin crystal. Plant Physiology, 115, 949-957.

[44] Shariffa, Y. N., Uthumporn, U., Karim, A. A. \& Zaibunnisa, A. H. (2017). Hydrolysis of native and annealed tapioca and sweet potato starches at subgelatinization temperature using a mixture of amylolytic enzymes. International Food Research Journal, 24, 1925-1933.

[45] Mohd, N. A., Amini, M. H. M. \& Masri M. N. (2016). Properties and characterization of starch as a naturalbinder: A brief overview. Journal of Tropical Resource and Sustainable Science, 4, 117-121.

[46] Gao, J., Luo, Z. G. \& Luo, F. X. (2012). Ionic liquids as solvents for dissolution of corn starch and homogeneous synthesis of fatty-acid starch esters without catalysts. Carbohydrate Polymers, 89, 1215-1221.

[47] Kuo, W. Y., \& Lai. H. M. (2007). Changes of property and morphology of cationic corn starches. Carbohydrate Polymers, 69, 544-553.

[48] Harry, T. F., Joel, O. F., Ademiluyi, F. T. \& Oduola, K. (2016). performance evaluation of local cassava starches with imported starch for drilling fluid. American Journal of Engineering Research, 5, 111-120. 